\title{
Submission of Manuscripts
}

All manuscripts should be submitted online at: http://www.edmgr.com/aeroj

Any enquiries should be directed to Wayne J Davis at aerojournal@ aerosociety.com.

The current set of instructions for authors are available at: http://journals.cambridge.org/AER

\section{Subscriptions}

The Aeronautical Journal (ISSN 0001-9240) is published monthly in 12 issues each year.

\section{Non-Members}

The subscription price (excluding VAT) to The Aeronautical Journal for volume 126 (2022), which includes print and electronic access, is $£ 672$ (USA, Canada and Mexico US\$1,006) and includes delivery by air; single

parts are available at £64 (USA, Canada and Mexico US\$96) plus postage. The electronic-only price available to institutional subscribers is $£ 588$ (USA, Canada and Mexico US\$882). EU subscribers (outside the UK) who are not registered for VAT should add VAT at their country's rate. VAT registered subscribers should provide their VAT registration number. Orders, which must be accompanied by payment, may be

sent to any bookseller or subscription agent or direct to the publishers: Cambridge University Press, University Printing House, Shaftesbury Road, Cambridge CB2 8BS, or in the USA, Canada, and Mexico to

Cambridge University Press, Journals Fulfillment Department, 1 Liberty Plaza, Floor 20, New York, NY 10006, USA. Japanese Prices for institutions are available from Kinokuniya Company Ltd, P.O. Box 55, Chitose, Tokyo, Japan.

\section{Advertising \\ All advertising enquiries should be sent to Neeral Patel partners@aerosociety.com \\ Internet Access}

The Aeronautical Journal is included in the Cambridge Journals Online service and can be found at: http://journals.cambridge.org/AER.

The Aeronautical Journal now supports open access publications across its hardcopy and online platforms, and accepts papers to consider for publication under both the 'green' and 'gold' open access options.

Information contained within The Aeronautical Journal has been published in good faith and the opinions expressed do not represent those of the Royal Aeronautical Society.

The Royal Aeronautical Society is a registered charity: No 313708

\section{(C) 2022 Royal Aeronautical Society}

All rights reserved. No part of this publication may be reproduced in any form or by any means, electronic, photocopying or otherwise, without permission in writing from Cambridge University Press. Permission to copy (for users in the USA) is available from the Copyright Clearance Center, http://www.copyright.com.

This journal issue has been printed on FSC $^{\text {TM }}$-certified paper and cover board. FSC is an independent, nongovernmental, not-for-profit organization established to promote the responsible management of the world's forests. Please see www.fsc.org for information.

Printed in Great Britain by Bell \& Bain Ltd, Glasgow. 


\section{CONTENTS}

Volume 126 Number 1295

January 2022

125 years of The Aeronautical Journal

Holger Babinsky FRAeS

Propulsive jet aerodynamics and aeroacoustics

J. J. McGuirk

NASA concept vehicles and the engineering of advanced air mobility aircraft

W. Johnson and C. Silva

Future aircraft concepts and design methods

R. A. McDonald, B. J. German, T. Takahashi, C. Bil, W. Anemaat, A. Chaput, R. Vos and N. Harrison

Transonic industrial wind tunnel testing in the $2020 \mathrm{~s}$

D. I. Greenwell

Helicopter Handling Qualities: A study in pilot control compensation

W. A. Memon, M. D. White, G. D. Padfield, N. Cameron and L. Lu

152

Dual-solver hybrid computational approaches for design

and analysis of vertical lift vehicles

M. J. Smith and A. Moushegian

Reviewing the impacts of climate change on air transport operations

G. B. Gratton, P. D. Williams, A. Padhra and S. Rapsomanikis

Progress in interlaminar toughening of aerospace polymer composites using particles and non-woven veils

O. İnal, K. B. Katnam, P. Potluri and C. Soutis

Front Cover: Aviation history montage.

(Wayne J Davis/RAeS) 